\title{
STUDENTS' OPINIONS ABOUT THE PROSPECTIVE HOSPITALITY MANAGER'S COMPETITIVENESS DURING PEDAGOGICAL EXPERIMENT
}

\author{
Sandra Iriste, Irena Katane \\ Latvia University of Agriculture \\ sandra.iriste@gmail.com
}

\begin{abstract}
Academic staff of higher education institutions has to extend students' vision and promote their variability of views on competitiveness in order to promote prospective hospitality managers' competitiveness. The aim and goal of academic activities of the university teaching staff is to search for appropriate or relevant means and provide the necessary conditions to foster the students' thinking and understanding of the concept of 'competitiveness' according to a new paradigm of this notion. The pedagogical experiment was carried out at the Latvia University of Agriculture. The aim of the study was to promote the opinions' change regarding the notion of prospective hospitality managers' competitiveness; the developed competitiveness self-assessment method was used as a pedagogical tool. The results of the research (the concluding statistics of the Wilcoxon test and the Sign Test) show that the students' opinions regarding the notion of prospective hospitality managers' competitiveness have significantly changed before and after their competitiveness self-assessment. Thus the theoretically grounded method of competitiveness self-assessment approved by students and experts, including a questionnaire of the students' survey, significantly extended the students' vision as a pedagogical tool influencing the opinions regarding competitiveness notion among representatives of the prospective hospitality managers' profession.

Key words: competitiveness, essays content analysis, competitiveness self-assessment method, pedagogical experiment, prospective hospitality managers.
\end{abstract}

\section{Introduction}

The notion competitiveness in modern educational space is used to denote the combination of personal and professional qualities of a prospective specialist based on the experience acquired during the life time, including education process which to a great extent characterizes one's flexibility and vitality in the time of dynamic and changeable environment. The human adaptation abilities to changeable conditions are both a prerequisite and a result of competitiveness development (Katane \& Iriste, 2013). Members of academic staff during the study process at the university have to foster the broadening of prospective hospitality managers' vision and changeability of opinions regarding competitiveness so that they can become competitive specialists. In order to ensure the competitiveness of students of any speciality, updated study plans have to be: flexible, they should comprise study courses demanded in both the market of education services and labour market, they should provide training of specialists in strategic directions, as well as, according to the current requirements, combine fundamental and innovative training. The aim and goal of academic activities of the university teaching staff is to search for appropriate or relevant means and provide the necessary conditions to foster the students' thinking and understanding of the concept of 'competitiveness' according to a new paradigm of this notion (Katane \& Kalniņa, 2010).

Currently not only a paradigm of personality's/ specialist's competitiveness is changing but also a paradigm of higher education in order to maintain sustainability of the society. The focus has shifted from the 'teacher-centred' approach to 'studentcentred' approach or from teaching to learning (Гребнев, 2004), because prospective specialists not only have to learn to acquire ready knowledge but they have to search answers to questions and solve problems by themselves during the study process. Globalisation process, the rapid development of science and introduction of innovation into our lives have led to an increase of new information flow at the huge scale and pace; information quickly is becoming obsolete. Therefore, the transition from factual learning to problem-based learning occurs promoting critical thinking, when prospective specialists have to develop judgment and decision-making abilities, creativity, media competence, including the ability to quickly find, evaluate and select the valid information they need.

The aim of the study was to promote the opinions' change regarding the notion of prospective hospitality managers' competitiveness.

\section{Materials and Methods}

The pedagogical experiment was carried out at the Latvia University of Agriculture and was one of several research stages. The developed competitiveness self-assessment method was used as a pedagogical tool.

The research took place at the Latvia University of Agriculture, Institute of Education and Home Economics, where prospective hospitality managers' competitiveness assessment method was developed, and at the Faculty of Food Technology, the Nutrition Department, where the experiment took place. The 
22 4th year undergraduate students of the study programme Catering and Hotel Management were invited to participate in the experiment.

The pedagogical experiment was held in 2015/2016 and comprised several stages (Fig. 1) described below:

- In March of 2016, the 22 4th year undergraduate students of the study programme Catering and Hotel Management wrote an essay 'Describe a competitive hospitality manager!'.

- In April of 2016, the 224 th year undergraduate students of the study programme Catering and Hotel Management performed competitiveness self-assessment of themselves as prospective hospitality managers applying the competitiveness self-assessment method worked out by the authors.

- In May 2016, the 22 4th year undergraduate students of the study programme Catering and Hotel Management wrote a repeated essay 'Describe a competitive hospitality manager!'.

The following research hypothesis was put forward: if competitiveness self-assessment method worked out by the authors of the article is applied as a pedagogical tool during the pedagogical experiment, it is possible to extend the prospective hospitality managers vision and promote the change of opinions regarding the notion of competitiveness in the context of the new paradigm.

The requirements for the essay 'Describe a competitive hospitality manager!' both before and after prospective hospitality managers completing the questionnaires were the following: 1) the size of an essay: 1 page, 2) the deadline of the submission into LLU e-learning environment: 2 weeks; 3 ) characters (with spaces) 5000 .

The essays 'Describe a competitive hospitality manager!' were submitted by each of 22 4th year students of study programme Catering and Hotel Management.

In order to find out if the students' opinion has changed regarding the notion of prospective hospitality managers competitiveness, students performed selfassessment of their competitiveness between the 1st and the 2 nd essay 'Describe a competitive hospitality manager!'. The research used the competitiveness selfassessment method theoretically grounded, approved by students and specialists-experts, including a questionnaire of the survey, as a pedagogical tool of the experiment in order to promote changes in students' opinions regarding the competitiveness of representatives of their profession.

The completion of the questionnaire took 35 minutes at the presence of the authors in the premises of the Nutrition Department.

The research data were obtained by analysing and evaluating essays using the method of content analysis.

The origins of the method of content analysis dates back to the beginning of the previous century; it has been included in the Webster's Dictionary since 1961 (according to Prasad, 2008). The founders of the content analysis are considered to be H. Lasswell (Lasswell, 1948), an American sociologist, who suggested to use statistical analysis for abstract linguistic units, and French journalist J. Kayser (Kayser \& Renouvin, 1963), who in the $60 \mathrm{~s}$ of the 20th century worked out the system for the analysis of long texts on the basis of statistical analysis.

Content analysis is the method in which verbal information is being translated into more objective nonverbal form (Пашинян, 2012) with the help of which:

1. the content of communication undergoes objective, systematic and qualitative analysis (Berelson, 1952) to measure variables (Kerlinger, 1986);

2. the obtained conclusions exceeds a specific character of a concrete document and are obtained on the basis of any data analysis of the meaning of its constituent elements (Kroplijs \& Raščevska, 2010);

3. documents are compressed and categorized in order to classify, systematize, tabulate their content (Дмитриев, 2005), discover or measure different facts and trends reflected

Prospective hospitality managers' competitiveness self-assessment method as the combination of tools of competitiveness increase

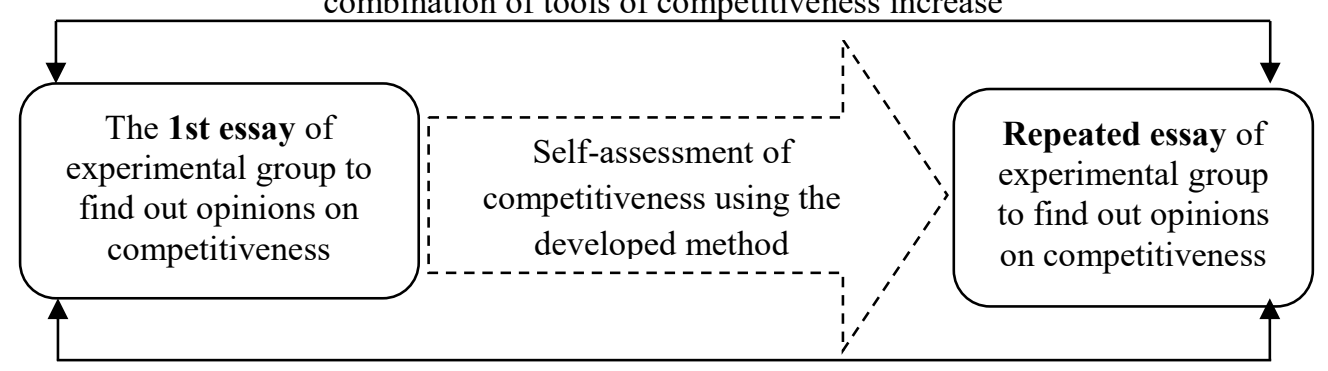

Figure 1. Procedure of the experiment (Source: constructed by the authors). 
in the social context of these documents

(Семёнова \& Корсунская, 2010).

The analysis of definitions of content analysis shows that the emphasis is placed on such aspects as regularity, objectivity, quantification, context and validity - with reference to the conclusions resulting from communication content of a message sender, message receiver.

Researchers distinguish between two levels of content analysis (Geske \& Grīnfelds, 2006): 1) manifest level is a descriptive account of the data without going into details of its meaning; 2) interpretive level reveals the meaning of content and conclusions that can be implied.

There are also two approaches of content analysis which often are combined (Kroplijs \& Raščevska, 2010).

- Inductive content analysis. It starts without previous theories, assumptions. The data are viewed as diffused, disorganized groups of separate pieces of information, each of which is worthy of attention. A researcher's task is to see the overlapping topics covered by these groups and provide some clarification on the issue under consideration.

- Deductive approach. It is based on clear assumptions which are based on theories. A researcher's task is to discover qualitative differences which reveal constructions of respondents' realities in a specific theme, instead of searching quantitative differences between an experimental and control group on some issue.

The content analysis contains several steps or stages of the analysis procedure (Josselson \& Lieblich, 1993; Дмитриев, 2005; Манекин, 1991; Семёнова \& Корсунская, 2010).

- A research question(s), objectives are set which a researcher desires to find out with the help of the content analysis.

- Selection of communication content and samples.

- Division of communication content into extracts or content units revealing a respondent's statements which characterise/ interpret his/her experience.

- The meaning of content units is explained and grouped in analytical categories. Thus experiences of individual respondents are combined building 'a bridge to another real-life situation'. The researcher expresses categories in the terms of psychology or education (abstract and general), otherwise the analysis will not generalize what respondents said and will be just a repetition of his/her words.
- Encoding and analysis of the obtained data.

- Fitting notions in a structure, i.e., a model or theory which could explain notions, scale, dynamics of phenomena, restrictions of existing theories or discovery of specific cases as well as formation of new theories.

The concept of content analysis is revealed by moving from a statement of a single respondent to a generalized scientific overlapping account of many statements.

With the help of content analysis it is possible to determine attitudes, trends of changes in opinions by analyzing texts of one or many authors of one subject field in the time period, as well as discover differences that characterize the content of texts of different authors.

Analysis of the research data. On the basis of developed and scientifically grounded structural competitiveness model of prospective hospitality managers, which include four components: selfconception, personality/professional direction, selfmanagement and competence of environment of professional activity, the system of 203 indicators for competitiveness self-assessment was worked out with four indicators' groups which students filled in before writing the $1^{\text {st }}$ essay 'Describe a competitive hospitality manager!'.

All 44 submitted essays were read for several times. Each essay was divided into extracts or content units which characterize/interpret the authors' of an essay experience regarding competitive hospitality manager. Initially these content units were written out, grouped in analytical categories, expressed in psychological terms and inserted in the table where all competitiveness indicators corresponded to the hospitality manager competitiveness self-assessment method worked out by the authors. The qualitative analysis was carried out comparing the data of the analysis of the 1st and 2nd essay. Furthermore, the results of the qualitative research were transformed into quantitative values, determining a frequency of collocations, phrases in relation to each competitiveness indicator. Mathematical analysis of data was carried out in the last stage in order to obtain descriptive statistics and concluding statistics using the Wilcoxon and the Sign test SPSS (21.0) software.

\section{Results and Discussion}

The analysis of the opinions' change in relation to structure components showed a significant difference in indicators of competitiveness component of competence of the repeated essays.

- In the Social and Cultural Competence these indicators were related to the ability to give a professional advise to colleagues, customers, importance of client-oriented thinking, such 
indicators as: an ability to include in unknown social environment and communication skills, also the knowledge of several languages. The significant extension of vision is related to the traineeship time (Management practice) which occurred between two essays, i.e., an opportunity to link theory (hospitality managers' competitiveness self-assessment questionnaire) with the environment of professional activity. It should be noted that an indicator of the knowledge of other and one's own culture was not mentioned in essays neither before nor after completion of hospitality managers' competitiveness selfassessment questionnaire. It is possible that such an erroneous opinion is caused by the idea that it is enough to know a foreign language to be aware of traditions of other cultures. However if the participants of intercultural communication process do not take into account the 'language code', traditions, norms, manifestations of social behaviour, there are possible communications failures that have more negative consequences than language mistakes (Гальскова \& Гез, 2006). In addition, an indicator of tolerance to sexual minorities was not related to competitiveness even though tolerance to ethnic minorities and knowledge of one's own culture and patriotism were mentioned. Accordingly, only a person who loves one's own country is active and responsible to become competitive hospitality manager.

- As regards 11 indicators of technology environment competence, only 3 indicators were mentioned in essays before completion of prospective hospitality managers' competitiveness self-assessment questionnaire: two students mentioned that competitive hospitality manager must be able to work with various computer software professionally, as well as they have to know cooking technologies. The hospitality managers' ability to transfer information (using modern and various technologies) quickly and qualitatively in real time shows their efficiency and competitiveness in the hospitality business (Щербаков, 2012). A significant increase of indicators after completion of prospective hospitality managers' competitiveness selfassessment questionnaire signifies that knowledge of different technologies and the ability to apply them is a significant competitive hospitality managers' indicator.

- Many indicators of informative environment competence mentioned in the essays after completion of prospective hospitality managers' competitiveness self-assessment questionnaire proves the fact that students, prospective hospitality managers, understand the importance of this competence in their future professional activities, however, it seems that they fail to completely distance themselves from unnecessary and even harmful information, which could adversely affect the professional activities, as well as it is necessary to work on information processing for the purpose of analysis of economic activities of a hospitality company.

- Students' opinions regarding indicators of business environment competence after completion of prospective hospitality managers' competitiveness self-assessment questionnaire have changed in the following way: the indicators 'wish and ability to promote one's own country's economic growth, competitiveness and sustainability by professional activities'; students wrote in the essays about the feeling of responsibility for their decisions, an ability to prepare descriptions of various procedures, the ability to analyse and evaluate technological processes of hotels and restaurants and business activities. The essays reflect an issue of food ingredients, which is a topical issue of catering business mostly regarding food allergens which should be identified in menus of catering companies and hospitality manager is directly responsible for food safety and its implementation (European Parliament and the Council, 2011). According to students' opinion, an important indicator is an ability to develop a hospitality product according to a profile of a company and the market demands since a hospitality company has to compete not only in its own country but also internationally, as the hospitality industry becomes one of the world's largest employers (World Tourism Organization, 2017). Only an innovative and different product is able to attract new and keep existing customers. Knowing what people want, delighting the customers by fully meeting their needs and expectations and creating memorable experiences consistently is key for successfull business (Melissen et al., 2014). Even though essays lack a range of indicators, these indicators have been highly evaluated in prospective hospitality managers' competitiveness self-assessment questionnaires therefore the authors make a conclusion that it is impossible to mention all indicators in essays but they are certainly 
important in competitive hospitality managers' professional activities.

- Any industry including hospitality area is influenced by state policy, its legislation by developing or braking business activities (Praude, 2011). Hospitality is one of the most intensely regulated industries in the world as it involves various risks to the health of clients. Statistics show that more than $80 \%$ of hospitality managers' professional activities are of a legal nature (Маноляк, 2007). As regards political and legal competence, only three out of ten indicators were mentioned before completion of prospective hospitality managers' competitiveness self-assessment questionnaire, but after its completion students mentioned seven indicators. However, such issues as labour security and legal knowledge are not reflected in the essays.

- The Component of Personality and Professional Direction. According to several scholars 'core' of personality is personality direction (Vanderbeeken \& Weber, 2002; Асмолов, 2002; Божович, 1968; Мерлин, 1996), which manifests itself in various spheres of human activity, including in the professional field (Ананьев, 1968; Леонтьев, 1977; Прангишвили, 1967; Рубинштейн, 1957). It is noteworthy that mentioning of such an indicator as love to work has increased significantly in the repeated essays. Students write that the work should be a hobby that prospective hospitality managers should be interested in everything related to hospitality, have a desire to improve professional knowledge, skills and competence in order to become a high-level professional and that prospective hospitality manager would be ready to improve business skills. In addition, students mention that it is necessary that other people, customers, staff members, relatives would respect and admire prospective hospitality managers for his/her success which is possible to achieve by providing products of high quality, by being able to adjust one's interests and aims to the interests and aims of other people, for example, customers, and a company. Prospective hospitality managers should feel a desire to help other people. Several studies (Hjalager, 2003; Teng, 2008) have emphasized the importance of this prospective hospitality managers' personality trait. Students' essays express an opinion that no one is perfect, even a manager, but everyone has to be psychologically ready to strive and achieve the goal by determining methods how to do that. Competitive, smart, strategically thinking entrepreneurs are able to transfer competitors into cooperation partners if they will be ready for a fair competition among other professionals. In spite of the fact that the authors of essays have a positive attitude towards the work in hospitality business and entrepreneurship, they do not consider this work to be prestigious. The authors of the paper emphasize that university lecturers working with prospective hospitality managers play an important role in the education process, they have to remind students that nothing can be more prestigious that to serve others by offering high quality products.

- The Component of Self-Conception. Selfconception is influenced by time, significant people and events from the past (Reece, 2013), it is mental picture of one's personality (Swann, Chang-Schneider, \& Larsen McClarty, 2007). Students' essays before and after completion of prospective hospitality managers' competitiveness self-assessment questionnaire contained an opinion that it is necessary for competitive hospitality manager to have a high level of knowledge, skills and competence in the area of hospitality. However, as regards the repeated essays, students increasingly mention high level of the knowledge in entrepreneurship. Hospitality manager has to be aware of his/ her physical, intellectual features, features of character, social maturity, they have to be able to objectively evaluate their knowledge and skills level in hospitality business. In addition, it is important to have self-respect, then others will evaluate correspondingly. Professor A.J. DuBrin (DuBrin, 2007) points out that employees who have ability to examine themselves and adapt their behavior receive better performance ratings, become leaders in the organizations. Competitive hospitality manager has to be a leader with a good sense of humour, negative experience should inspire to become a good specialist, generates internal defiance and determination to overcome one's weakness, inability and shortcomings. The job should be done in the best possible way.

- The Component of Self-Management. As regards self-management component indicators, only seven were mentioned out of thirty three indicators in the students' essays before the completion of prospective hospitality managers' competitiveness selfassessment questionnaire. The vision has significantly extended after the completion of the questionnaire: students think that 
competitive hospitality manager should be flexible in thinking, decisions and actions, they have to be able to implement innovations simultaneously working according to certain standards even if they fully do not agree with them due to the fact that hospitality business is being strictly regulated by the law. Scientist D. Kryukov (Крюков, 2012) points out that the prospective hospitality managers can knowingly change not only the external conditions of existence and life activities, but also own inner world, himself, personality properties and character; can widen the range of their potential (to develop their career) thanks to the understanding and transformation of those own qualities, which hinder or promote competitiveness. The work with people creates many various unexpected situations which should be dealt with immediately; therefore people engaged in hospitality business should be particularly stress-persistent; it is possible when one takes care of one's health.

As it was mentioned before, after encoding the data of competitiveness indicators found in the prospective hospitality managers' essays and the primary statistical analysis of the data, the secondary statistical analysis was carried out for obtaining concluding statistics. Two tests were used for this purpose: the Wilcoxon and the Sign test SPSS (21.0) software.

Two hypotheses were put forward:

$\mathbf{H}_{0}$ : students' opinions have not changed on the competitive hospitality managers after self-assessment of their competitiveness during the pedagogical experiment:

1 st essay results $=2$ nd essay results.

$\mathbf{H}_{1}$ : students' opinions have changed on the competitive hospitality managers after self-assessment of their competitiveness during the pedagogical experiment:
1 st essay results $\neq 2$ nd essay results

The Wilcoxon test results were obtained which gave evidence that changes have occurred in 135 indicators and only 68 indicators have not changed.

Concluding statistics of the Wilcoxon test results show that: $p$-value $=0.000<\alpha=0.001$, which means that changes in students' opinions on competitive hospitality managers during the experiment are distinctly significant.

The Sign test results did not differ from the Wilcoxon test results.

\section{Conclusions}

1. With the help of content analysis it is possible to determine prospective hospitality managers attitudes, trends of opinion changes, analyzing one text or texts of many authors of the same subject field in time, as well as to reveal differences which characterize the content of texts of many authors.

2. The results of both the Wilcoxon test and the Sign Test show positive changes in 118 indicators out of 203 indicators. The concluding statistics of the Wilcoxon test and the Sign Test give evidence that the students' opinion on the notion of competitiveness and competitive hospitality managers have significantly changed during the pedagogical experiment, because $\mathrm{p}$-value $=0.000$ $<\alpha=0.001$.

3. The proposed hypothesis was tested during the pedagogical experiment. It is possible to extend students' vision significantly if the developed, scientifically grounded method worked out by the authors and approved by students and specialistsexperts, including a questionnaire of the survey, as a pedagogical tool of the experiment in order to promote changes in students' opinions regarding the competitiveness of representatives of their profession, is applied.

\section{References}

1. Berelson, B. (1952). Content analysis in communication research. New York: The Free Press.

2. Dubrin, A.J. (2007). Leadership Research: Findings, Practice, and Skills (5th ed.). Boston: Houghton Mifflin Company.

3. European Parliament and the Council (2011). Regulation No 1169/2011 on the provision offood information to consumers.

4. Geske, A., \& Grīnfelds, A. (2006). Izglītības pētniecība (Educational research). Rīga: LU Akadēmiskais apgāds. (in Latvian).

5. Hjalager, A-M. (2003). Global Tourism Careers: Opportunities and Dilemmas Facing Higher Education in Tourism. The Journal of Hospitality Leisure Sport and Tourism. 2(2), 26 - 38. DOI: 10.3794/johlste.22.35.

6. Josselson, R., \& Lieblich, A. (1993). A narrative introduction. In R. Josselson \& A. Lieblich (Eds.), The narrative study of lives (pp. ix - xv). Newbury Park, CA: Sage.

7. Katane, I., \& Iriste, S. (2013). Students' as Prospective Hospitality Specialists' Competitiveness in Theory and Practice. In Proceegings of the Internetational Scietific Conference Society. Integration. Education (Vol. 1, pp. 119 - 129). Rezekne: RA. DOI: 10.17770/sie2013vol1.158. 
8. Katane, I., \& Kalniņa, I. (2010). Skolēnu personības konkurētspējas attīstība neformālās komercizglītības vide (Development of secondary school pupils' competitiveness within the environment of non-formal commercial education). Jelgava: LLU. (in Latvian).

9. Kayser, J., \& Renouvin, P. (1963). Le quotidien français (The French daily). Paris: A. Colin. (in French).

10. Kerlinger, F.N. (1986). Foundations of behavioral research (3rd ed). New York: Holt, Rinehart and Winston.

11. Kroplijs, A., \& Raščevska, M. (2010). Kvalitatīvās pētniecības metodes sociālajās zinātnēs (Qualitative research methods in social sciences). Rīga: RaKa. (in Latvian).

12. Lasswell, H. (1948). Power and Personality. New York: NY.

13. Melissen, F., Rest, J., Josephi, S., \& Blomme, R. (2014). Hospitality Experience: An Introduction to Hospitality Management. Groningen: Noordhoff Publishers BV.

14. Prasad, D. (2008). Content analysis: A method of Social Science Research. In D.K. Lal Das (Ed.), Research Methods for Social Work (pp. 174 - 193). New Delhi: Rawat Publications.

15. Praude, V. (2011). Mārketings. Teorija un prakse (Marketing. Theory and praxis). Rīga: I. Burtene SIA. (in Latvian).

16. Reece, B.L. (2013). Effective Human Relations: Interpersonal and Organizational Applications (12th ed.). South-Western, USA: Cengage Learning.

17. Swann, W.B., Chang-Schneider, C., \& Larsen McClarty, K. (2007). Do people's self-views matter? Selfconcept and self-esteem in everyday life. American Psychologist. 62(2), 84 - 94. DOI: 10.1037/0003066X.62.2.84.

18. Teng, C.C. (2008). The effects of personality traits and attitudes on student uptake in hospitality employment. International Journal of Hospitality Management. 27(1), 76 - 86. DOI: 10.1016/j.ijhm.2007.07.007.

19. Vanderbeeken, R., \& Weber, E. (2002). Dispositional explanations of behavior. Behavior and Philosophy. $30,43-59$.

20. World Tourism Organization (2017). UNWTO Annual Report 2016. Retrieved July 10, 2017, from: http:// cf.cdn.unwto.org/sites/all/files/pdf/annual_report_2016_web_0.pdf.

21. Ананьев, Б.Г. (1968). Человек как предмет познания (Man as the object of cognition). Ленинград: ЛГУ. (in Russian).

22. Асмолов, А.Г. (2002). Психология личности: принципы общепсихологического анализа (Personality psychology: principles general psychological analysis). Москва: Смысл. (in Russian).

23. Божович, Л.И. (1968). Личность и ее формирование в детском возрасте (The personality and its formation at children's age). Москва: Педагогика. (in Russian).

24. Гальскова, Н.Д., \& Гез, Н.И. (2006). Теория обучения иностранным языкам. Лингводидактика и методика (Theory of teaching foreign languages. Linguodidactics and methodology). Москва: Академия. (in Russian).

25. Гребнев, Л. (2004). Высшее образование в Болонском измерении: российские особенности и ограничения (Higher education in the Bologna measurement: Russian features and limitations). Высшеe образование в России, 1, 36-42. (in Russian).

26. Дмитриев, И. (2005). Контент-анализ: сущность, задачи, процедуры (Content analysis: essence, tasks, procedures). Санкт-Петербург: Питер. (in Russian).

27. Крюков, Д. (2012). Психологические аспекты личной конкурентоспособности предпринимателя (Psychological aspects of entrepreneur's personal competitiveness). Современная конкуренция. 4(34), 11 - 24. (in Russian).

28. Леонтьев, А.Н. (1977). Деятельность. Сознание. Личность (Activity. Consciousness. Personality). Москва: Политиздат. (in Russian).

29. Манекин, Р.В. (1991). Контент-анализ как метод исторического исследования (Content-analysis as a method of historical research). Международный ежеквартальный научно-исторический журнал Донецкого отделения Советской Ассоциации Молодых Историков и Агентства Информсервис, 2, 30 - 36. (in Russian).

30. Маноляк, В.Ю. (2007). Формирование профессионально-правовой компетентности студентов туристского вуза (Formation of professionally oriented legal competence of the tourism students). Doctoral dissertation, Российская международная академия туризма, Москва, Россия. (in Russian).

31. Мерлин, В.С. (1996). Психология индивидуальности (Individuality psychology). Москва: Институт практической психологии. (in Russian). 
32. Пашинян, И.А. (2012). Контент-анализ как метод исследования: достоинства и ограничения (Content analysis as a method of research: advantages and limitations). Научная периодика: проблемы и решения, 3(9), 13 - 18. (in Russian).

33. Прангишвили, А.С. (1967). Исследование по психологии установки (Study of the psychology of set). Тбилиси: Мецниереба. (in Russian).

34. Рубинштейн, С.Л. (1957/2003). Бытие и сознание (Social being and consciousness). Санкт-Петербург: Питер. (in Russian).

35. Семёнова, А.В., \& Корсунская, М.В. (2010). Контент-анализ СМИ: проблемы и опыт применения (Content analysis of mass media: problems and practices). Москва: Институт социологии РАН. (in Russian).

36. Щербаков, Г.С. (2012). Модель развития профессиональной направленности информационнотехнологической подготовки будущих менеджеров туризма (Development model of professional orientation of information technology training of future tourism managers). Вестник РМАТ, 2(5), 130 - 132. (in Russian). 